\title{
Structure and Diversity In Ombrophilous Forest in the Zona da Mata of Pernambuco
}

\author{
Rosival Barros de Andrade Lima ${ }^{1}$ (D), Luiz Carlos Marangon ${ }^{1}$ (D), \\ Fernando José Freire $^{2}$ (D), Ana Licia Feliciano ${ }^{1}$ (D), \\ Roseane Karla Soares de Silva ${ }^{1}$
}

${ }^{1}$ Departamento de Ciências Florestais, Universidade Federal Rural de Pernambuco - UFRPE, Recife/PE, Brasil ${ }^{2}$ Departamento de Agronomia, Universidade Federal Rural de Pernambuco - UFRPE, Recife/PE, Brasil

\begin{abstract}
The objective of this work was to evaluate the arboreal component of a Dense Ombrophilous Lowland Forest fragment through evaluations of richness, structure and diversity. For the sampling of this component, we implanted 40 sample units of $10 \times 25 \mathrm{~m}$. We measured all arboreal individuals who presented circumference at breast height $\geq 15 \mathrm{~cm}, 1.30 \mathrm{~m}$ from the ground level. The tree stratum presented 1324 individuals, 100 species, 64 genera and 38 families. The Fabaceae family had the highest wealth and Anacardiaceae was the most abundant. The Shannon index and Pielou equability were 3.60 nats.ind. ${ }^{-1}$ and 0.78 , respectively, suggesting the existence of relevant ecological dominance in the community. The results of this work emphasize the ecological importance of this remnant for maintaining the local flora and fauna, also emphasizing the importance of preserving Atlantic Ombrophilous Forests, particularly in the Zona da Mata of Pernambuco.
\end{abstract}

Keywords: phytosociology, atlantic forest, floristic. 


\section{INTRODUCTION}

Forests constantly change their structure, physiognomy and floristic composition until climax (Téo et al., 2014). A way to detect the current state of these forests is through floristic and vegetation structure analysis, which provides a necessary ecological basis for quantitative and qualitative inferences of the forest structure (Silva \& Bentes-Gama, 2008). Studies of this nature provide us with important data for restoration, conservation and management of natural resources, contributing to the maintenance of the high diversity of species and habitats (Silva et al., 2011).

The situation of tropical forests is disturbing due to several factors that promote fragmentation, loss of habitat and biodiversity (Laurance et al., 2017), such as: logging, agricultural area expansion, extensive livestock production, and especially the increase in the population (Roa-Romero et al., 2009; Vega et al., 2016). As the population increases, the consumption standard rises, which increases the demand for natural resources, promoting the degradation of ecosystems with serious consequences for the present society and future generations (Philippi et al., 2012).

Such degradations cause important ecosystems to be decharacterized even before their original floristic composition is known (Silva et al., 2008). According to Cordeiro et al. (2011), floristic composition knowledge is the first step towards understanding the real dimensioning of local biodiversity.

In addition to assisting in ecosystem management and conservation, the information generated in floristic-structural studies also helps in planning management practices aimed at recovery of degraded areas (Hernández-Ramírez \& García-Méndez, 2015). In this aspect, the objective of the present study was to characterize the floristic composition and the structure of an Atlantic Forest fragment in order to obtain basic information that will result in support tools for management and conservation of the Atlantic Forest, especially in the Zona da Mata of Pernambuco.

\section{MATERIAL AND METHODS}

\subsection{Study area}

The study was conducted in an Ombrophilous Lowland Forest fragment (Martins \& Cavararo, 2012). This fragment has 42 ha called Coelhas and belongs to the
Usina Trapiche S/A, municipality of Sirinhaém, located in the southern region of Pernambuco state (Figure 1).

Forests in this region are currently circumvented by extensive sugar cane plantations or even by urban areas, clearly reducing the extent of areas with large forests. The fragment studied is in this situation and has already suffered deforestation, being surrounded by the sugar cane matrix, but currently it is well preserved.

According to the Köppen classification, the region presents an Am monsoon climate (Alvares et al., 2013) with annual average temperature of $25.6^{\circ} \mathrm{C}$. The average altitude is $60 \mathrm{~m}$ and the period of greatest rainfall begins in April and ends in September. The average annual rainfall of the region from March/2011 to April/2016 was approximately 1,860 $\mathrm{mm}$ (Oliveira et al., 2016). The predominant soils in the study area are: Yellow Latosol; Yellow, Red-Yellow and Greyish Argisols; Gleysol; Cambisol; and Flossic Neosols (Silva et al., 2001; Santos et al., 2013).

\subsection{Data collection}

For the tree component sampling we systematically implanted 40 sample units of $10 \times 25 \mathrm{~m}\left(250 \mathrm{~m}^{2}\right)$, the equivalent of $1 \mathrm{ha}$ of sampled area and distance between $42 \mathrm{~m}$ plots. We georeferenced all sample units and sampled all tree individuals that presented circumference at breast height $(\mathrm{CBH}) \geq 15 \mathrm{~cm}$, at $1.30 \mathrm{~m}$ above ground level. We measured this using a tape measure, and estimated height with high pruning shears of six meters in length. All the sampled individuals received PVC plates $(3 \times 5 \mathrm{~cm})$ with increasing numeration, which were nailed $15 \mathrm{~cm}$ above the measurement point.

We identified the species whenever possible in the field. When necessary, we collected plant material to help the identification by professionals from the Dárdano de Andrade Lima Herbarium of the Agronomic Institute of Pernambuco (IPA). We used the Angiosperm Phylogeny Group classification system to classify the families (APG IV, 2016). Spelling and the names of the species were checked through the Missouri Botanical Garden website (Tropicos.org, 2017).

\subsection{Data analysis}

\subsubsection{Sample sufficiency}

We evaluated the floristic sufficiency from the rarefaction curve using EstimateS 9.1.0 Software (Colwell, 2013). Sampling sufficiency was determined 


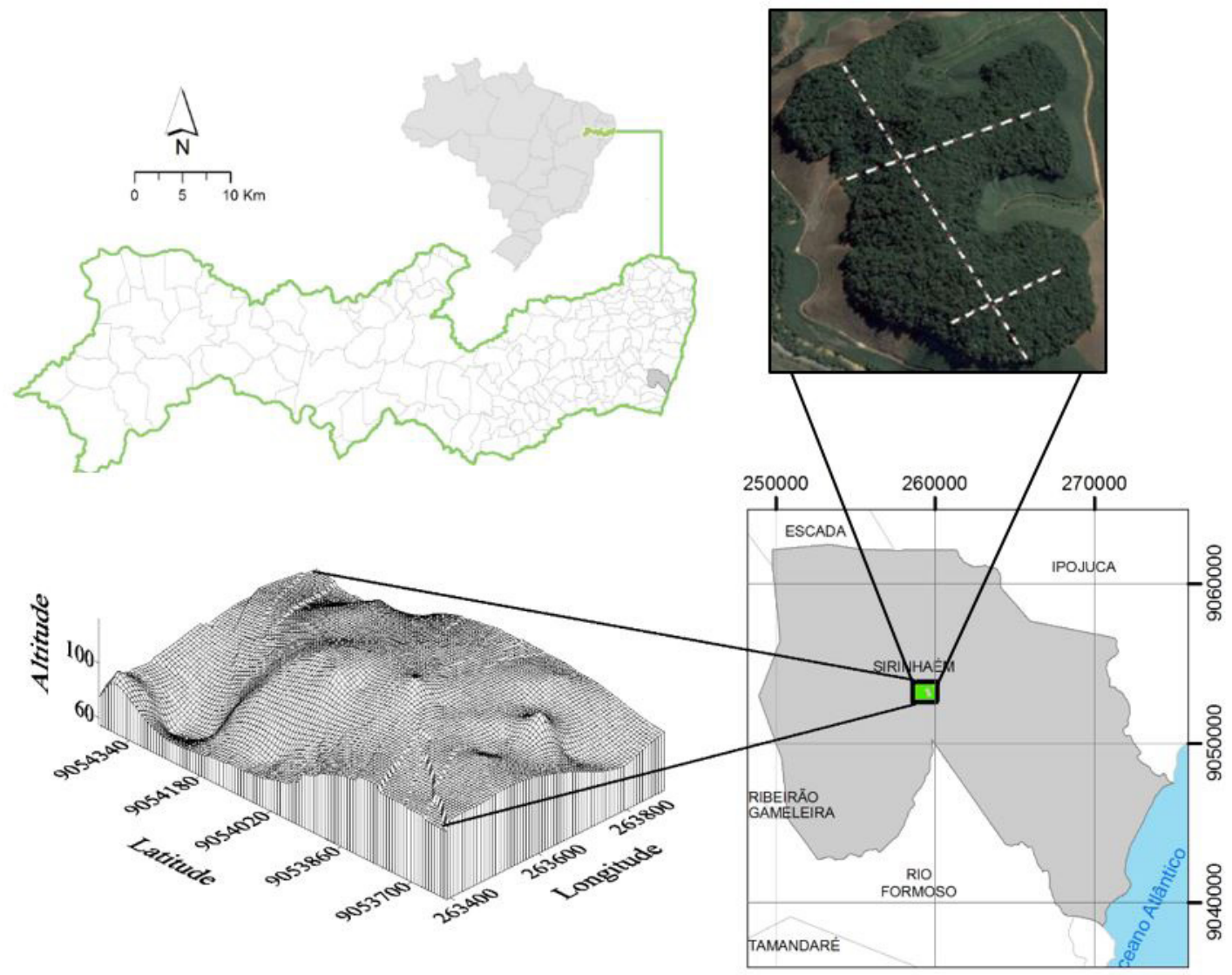

Figure 1. Geographic location of the Coelha Forest, Usina Trapiche S/A, Sirinhaém, Pernambuco, Brazil. (Source: Walter Lucena).

by considering the random sampling estimators based on three parameters: number of individuals, mean diameters and mean height, where we performed the calculations of sample errors (Ea\%) at a $95 \%$ probability level, assuming a sample error of at most $15 \%$.

\subsubsection{Floristic composition and successional classification}

After surveying and identifying the species, we compiled a list containing the species, genera, number of individuals and families of all individuals found in the tree component according to the APG IV classification system. We adopted the criterion suggested by Gandolfi et al. (1995) for species classification by successional group, in which the species were classified as pioneers, early secondary, late secondary or uncharacterized. We performed the classification through field observations and bibliographic research
(Gandolfi et al., 1995; Brandão et al., 2009; Oliveira et al., 2011; Silva et al., 2010).

\subsubsection{Phytosociological structure and diversity and equability indexes}

We evaluated the following phytosociological parameters: Absolute Density (AD), Relative Density (RD), Absolute Frequency (AF), Relative Frequency (RF), Absolute Dominance (ADo), Relative Dominance (RDo), Coverage Value (CV), Importance Value (IV). These parameters were calculated using the Fitopac 2 software tool. We also calculated the Shannon diversity indexes $\left(\mathrm{H}^{\prime}\right)$ and the Pielou equability index (J) (Pielou, 1975), as proposed by Magurran (1988).

\subsubsection{Diametric and hypsometric distribution}

For the analysis of the diametric distribution, we plotted the number of individuals per diametric class center, where the number of class centers and their 
amplitude were calculated based on Sturges (1926), through Equations 1 and 2:

$$
\begin{aligned}
& N C=1+\left(3.322 * \log \left(N_{\text {ind. }}\right)\right) \\
& T A=X-x / N C
\end{aligned}
$$

Where: $N C=$ number of classes; $N_{\text {ind. }}=$ number of individuals; $T A$ = total amplitude; $X=$ largest diameter and $x=$ smallest diameter.

For analysing the hypsometric structure, we generated a graph with the number of individuals per height class center, with an amplitude of $5 \mathrm{~m}$ and the first class beginning at $2.5 \mathrm{~m}$.

\section{RESULTS AND DISCUSSION}

\subsection{Sample sufficiency}

The floristic sufficiency was considered satisfactory as given by the asymptote and stability in the confidence intervals of the rarefaction curve calculated for species richness (Figure 2).

The calculated sample errors were lower than the established error (15\%). For the number of individuals, diameter means and height means, the sample error values were: Ea $6.79 \%, 4.59 \%$ and $3.76 \%$, respectively. These results indicate that the sampling was sufficient to represent the plant community of the area.

\subsection{Floristic composition and successional classification}

Tree sampling recorded 1,324 individuals, belonging to 100 species, 64 genera and 38 families. Among these species, 81 were identified at the species level, 13 at the gender level, five at the family level and one was not identified (Table 1).

The families with the highest representativity of individuals were: Anacardiaceae (314 individuals), Burseraceae (141), Moraceae (133), Melastomataceae (100), Fabaceae (82), Lecythidaceae (71), Myrtaceae (68), Euphorbiaceae Lauraceae (39) and Salicaceae (38), added together totalled 1,044 individuals. These ten families represented $78.85 \%$ of the individuals sampled. The other families (28) accounted for $21.15 \%$ of the total, evidencing the low relative abundance of individuals in these families. The Anacardiaceae family, which obtained the largest number of individuals in this study, was also the most outstanding in a study by Costa et al. (2008) for the same typology. This higher representation may be related to the fact that this family has approximately 81 genera and 800 species, with occurrence in dry to humid environments, mainly in lowlands in tropical and subtropical regions around the world (Pell et al., 2011). Fruit from the Thyrsodium spruceanum species (Anacardiaceae) are drupe and are very appreciated by the fauna, suggesting

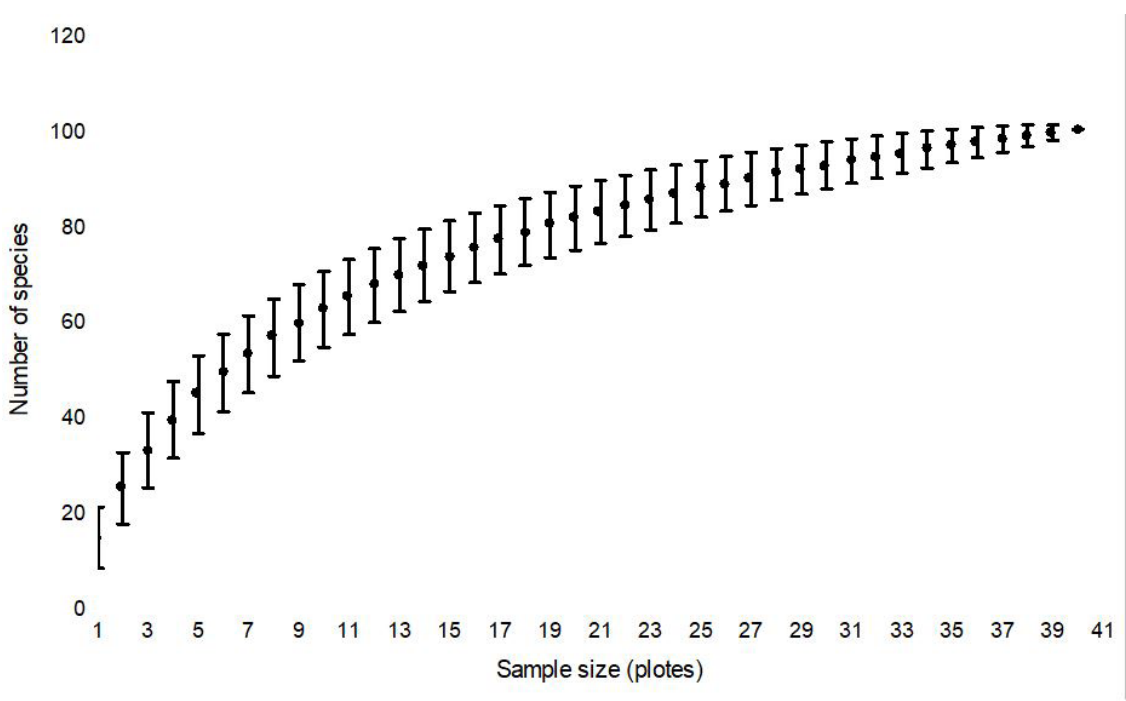

Figure 2. Species accumulation curve in the Coelha Forest, Usina Trapiche S/A, Sirinhaém, Pernambuco, Brazil (rarefaction method). Vertical bars represent the confidence interval (95\%). 
Table 1. Floristic composition of tree species $(\mathrm{CBH} \geq 15 \mathrm{~cm})$ registered in the Coelha Forest, Usina Trapiche S/A, Sirinhaém, Pernambuco. In alphabetical order of family, gender and species, where: $\mathrm{N}_{\mathrm{i}}=$ Number of individuals and EG = Ecological group; P = Pioneer; IS = Initial secondary; LS = Late secondary; Nc = Not classified.

\begin{tabular}{|c|c|c|c|}
\hline Family & Specie & $\mathbf{N}_{\mathbf{i}}$ & EG \\
\hline \multirow{2}{*}{ Anacardiaceae } & Tapirira guianensis Aubl. & 68 & IS \\
\hline & Thyrsodium spruceanum Benth. & 246 & IS \\
\hline \multirow{2}{*}{ Annonaceae } & Guatteria pogonopus Mart. & 17 & Nc \\
\hline & Xylopia frutescens Aubl. & 3 & IS \\
\hline Apocynaceae & Himatanthus phagedaenicus (Mart.) Woodson & 26 & IS \\
\hline Araliaceae & Schefflera morototoni (Aubl.) Maguire, Steyerm. \& Frodin & 33 & IS \\
\hline Boraginaceae & Cordia sellowiana Cham. & 7 & IS \\
\hline \multirow{2}{*}{ Burseraceae } & Protium giganteum Engl. & 7 & LS \\
\hline & Protium heptaphyllum (Aubl.) Marchand & 134 & IS \\
\hline Celastraceae & Maytenus distichophylla Mart. ex Reissek & 3 & LS \\
\hline \multirow{3}{*}{ Clusiaceae } & Rheedia gardneriana Planch. \& Triana & 1 & LS \\
\hline & Symphonia globulifera L. f. & 12 & $\mathrm{P}$ \\
\hline & Tovomita mangle G. Mariz & 3 & IS \\
\hline Combretaceae & Buchenavia tetraphylla (Aubl.) R.A. Howard & 1 & LS \\
\hline \multirow{2}{*}{ Elaeocarpaceae } & Sloanea garckeana K. Schum. & 1 & LS \\
\hline & Sloanea guianensis (Aubl.) Benth. & 1 & LS \\
\hline \multirow{3}{*}{ Erythroxylaceae } & Erythroxylum citrifolium A. St.-Hil. & 2 & LS \\
\hline & Erythroxylum mucronatum Benth. & 14 & LS \\
\hline & Erythroxylum squamatum Sw. & 1 & LS \\
\hline Euphorbiaceae & Maprounea guianensis Aubl. & 29 & IS \\
\hline \multirow{12}{*}{ Fabaceae } & Abarema sp. & 3 & Nc \\
\hline & Albizia pedicellaris (DC.) L. Rico & 6 & $\mathrm{P}$ \\
\hline & Andira ormosioides Benth. & 2 & IS \\
\hline & Bowdichia virgilioides Kunth & 12 & LS \\
\hline & Chamaecrista sp. & 14 & $\mathrm{Sc}$ \\
\hline & Dialium guianense (Aubl.) Sandwith & 3 & LS \\
\hline & Fabaceae 1 & 2 & Nc \\
\hline & Fabaceae 2 & 4 & Nc \\
\hline & Fabaceae 3 & 1 & Nc \\
\hline & Fabaceae 4 & 5 & Nc \\
\hline & Inga cayennensis Sagot ex Benth. & 3 & IS \\
\hline & Inga sp.1 & 2 & Nc \\
\hline \multirow{7}{*}{ Fabaceae } & Inga sp. 2 & 1 & Nc \\
\hline & Inga thibaudiana DC. & 6 & IS \\
\hline & Machaerium hirtum (Vell.) Stellfeld & 1 & IS \\
\hline & Parkia pendula (Willd.) Benth. ex Walp. & 8 & LS \\
\hline & Plathymenia foliolosa Benth. & 3 & IS \\
\hline & Sclerolobium densiflorum Benth. & 3 & $\mathrm{P}$ \\
\hline & Swartzia pickelii Killip ex Ducke & 3 & IS \\
\hline Hypericaceae & Vismia guianensis (Aubl.) Choisy & 1 & $\mathrm{P}$ \\
\hline Lacistemataceae & Lacistema robustum Schnizl. & 5 & IS \\
\hline \multirow{6}{*}{ Lauraceae } & Nectandra cuspidata Nees \& Mart. & 10 & LS \\
\hline & Ocotea gardneri (Meisn.) Mez & 1 & IS \\
\hline & Ocotea glomerata (Nees) Mez & 10 & IS \\
\hline & Ocotea sp. 1 & 13 & Nc \\
\hline & Ocotea sp. 2 & 3 & $\mathrm{Nc}$ \\
\hline & Ocotea sp. 3 & 2 & Nc \\
\hline
\end{tabular}


Table 1. Continued...

\begin{tabular}{|c|c|c|c|}
\hline Family & Specie & $\mathbf{N}_{\mathbf{i}}$ & EG \\
\hline \multirow{4}{*}{ Lecythidaceae } & Eschweilera ovata (Cambess.) Miers & 52 & IS \\
\hline & Gustavia augusta L. & 3 & IS \\
\hline & Lecythis pisonis Cambess. & 1 & IS \\
\hline & Lecythis lurida (Miers) S.A. Mori & 15 & $\mathrm{Nc}$ \\
\hline Malvaceae & Eriotheca macrophylla (K. Schum.) A. Robyns & 6 & IS \\
\hline \multirow{8}{*}{ Melastomataceae } & Henriettea succosa (Aubl.) DC. & 16 & Nc \\
\hline & Miconia affinis DC. & 31 & $\mathrm{Nc}$ \\
\hline & Miconia hypoleuca (Benth.) Triana & 20 & IS \\
\hline & Miconia minutiflora (Bonpl.) DC. & 3 & IS \\
\hline & Miconia prasina (Sw.) DC. & 6 & $\mathrm{P}$ \\
\hline & Miconia pyrifolia Naudin & 9 & IS \\
\hline & Miconia sp. & 4 & Nc \\
\hline & Miconia tomentosa (Rich.) D. Don ex DC. & 11 & IS \\
\hline \multirow{5}{*}{ Moraceae } & Artocarpus heterophyllus Lam. & 1 & $\mathrm{Nc}$ \\
\hline & Brosimum guianense (Aubl.) Huber & 55 & IS \\
\hline & Brosimum rubescens Taub. & 39 & IS \\
\hline & Helicostylis tomentosa (Poepp. \& Endl.) Rusby & 36 & IS \\
\hline & Sorocea hilarii Gaudich. & 2 & IS \\
\hline Myristicaceae & Virola gardneri (A. DC.) Warb. & 12 & LS \\
\hline \multirow{7}{*}{ Myrtaceae } & Eugenia umbelliflora O. Berg & 1 & IS \\
\hline & Eugenia umbrosa O. Berg & 2 & IS \\
\hline & Myrcia guianensis (Aubl.) DC. & 2 & IS \\
\hline & Myrcia silvatica Barb. Rodr. & 43 & IS \\
\hline & Myrcia spectabilis DC. & 11 & IS \\
\hline & Myrcia splendens (Sw.) DC & 6 & IS \\
\hline & Myrtaceae 1 & 3 & Nc \\
\hline Nyctaginaceae & Guapira opposita (Vell.) Reitz & 2 & IS \\
\hline Ochnaceae & Ouratea polygyna Engl. & 15 & IS \\
\hline \multirow{3}{*}{ Peraceae } & Chaetocarpus myrsinites Baill. & 4 & Nc \\
\hline & Pera ferruginea (Schott) Müll. Arg. & 16 & IS \\
\hline & Pogonophora schomburgkiana Miers ex Benth. & 13 & LS \\
\hline Phyllanthaceae & Hyeronima alchorneoides Allemão & 29 & IS \\
\hline Picramniaceae & Picramnia sp. & 4 & $\mathrm{Nc}$ \\
\hline Primulaceae & Rapanea guianensis Aubl. & 1 & $\mathrm{P}$ \\
\hline Rubiaceae & Amaioua sp. & 1 & $\mathrm{Nc}$ \\
\hline \multirow{2}{*}{ Salicaceae } & Casearia arborea (Rich.) Urb. & 3 & IS \\
\hline & Casearia javitensis Kunth & 35 & LS \\
\hline \multirow{5}{*}{ Sapindaceae } & Cupania emarginata Cambess. & 2 & IS \\
\hline & Cupania racemosa (Vell.) Radlk. & 11 & IS \\
\hline & Cupania revoluta Rolfe & 5 & IS \\
\hline & Cupania sp. & 1 & $\mathrm{Nc}$ \\
\hline & Talisia retusa R.S. Cowan & 1 & IS \\
\hline \multirow{4}{*}{ Sapotaceae } & Pouteria bangii (Rusby) T.D. Penn. & 11 & LS \\
\hline & Pouteria sp. & 1 & Nc \\
\hline & Pouteria torta (Mart.) Radlk. & 2 & LS \\
\hline & Pradosia sp. & 1 & $\mathrm{Nc}$ \\
\hline Schoepfiaceae & Schoepfia brasiliensis A. DC. & 5 & IS \\
\hline Simaroubaceae & Simarouba amara Aubl. & 12 & IS \\
\hline Siparunaceae & Siparuna guianensis Aubl. & 5 & IS \\
\hline
\end{tabular}


Table 1. Continued...

\begin{tabular}{llcc}
\multicolumn{1}{c}{ Family } & \multicolumn{1}{c}{ Specie } & $\mathbf{N}_{\mathbf{i}}$ & EG \\
\hline Urticaceae & Pourouma acutiflora Trécul & 6 & IS \\
\hline Violaceae & Paypayrola blanchetiana Tul. & 2 & Nc \\
\hline Undetermined 1 & Undetermined 1 & 9 & Nc \\
\hline Total & & $\mathbf{1 , 3 2 4}$ & \\
\hline
\end{tabular}

that the high number of individuals of this species is justified by the wide zoochoric dispersion.

The Fabaceae family presented higher richness (19 species), and also being of greater wealth in works carried out in Pernambuco state (Guimarães et al., 2009; Silva et al., 2010). The Fabaceae family is one of the three most representative families of angiosperm flora mainly due to its wide dispersion, as well as its important ornamental and ecological role, mainly in atmospheric and soil nitrogen fixation, thus emphasizing its importance and necessary knowledge (Malczewski et al., 2014).

Twenty species were represented by only one individual (20\% of the total species), being considered locally rare. According to Brandão et al. (2011), these species are only rare in the numerical concept for a given area, in a given moment, and not necessarily from the biological point of view, since they may occur in higher densities in close fragments.

Among the characterized species, the group of initial secondary is highlighted with $67 \%$, the pioneers represented $8 \%$, and the late secondary $25 \%$. A predominance of initial succession species was verified, since the pioneer and secondary species represented $75 \%$ of the species inventoried in the tree stratum. The results are similar to those reported by Brandão et al. (2009) and Silva et al. (2010) for the same typology, inferring that the studied environment is in an intermediate succession stage. An evaluation of the parameters contained in CONAMA Resolution no. 31 of December 7, 1994 was also performed, proving that the fragment is in the middle successional stage.

\subsection{Phytosociological structure and diversity and equability indexes}

The density was estimated at $1324 \mathrm{ind} \mathrm{ha}^{-1}$. From the total, Thyrsodium spruceanum (246 individuals), Protium heptaphyllum (134) and Tapirira guianensis (68) species corresponded to $33.84 \%$ of the individuals sampled (Table 2). These species also stood out in number of individuals in other studies carried out in the Atlantic Forest of Pernambuco (Brandão et al., 2009; Silva et al., 2012).

The most frequent species in the sample area were Thyrsodium spruceanum, Protium heptaphyllum, Eschweilera ovata, Tapirira guianensis, Brosimum guianense, Schefflera morototoni and Myrcia silvatica. The species Thyrsodium spruceanum was recorded in $97.50 \%$ of the sample units, meaning it was present in 39 of the 40 plots. The occurrence of many individuals of species belonging to the Anacardiacea family is common in the Atlantic Forest. As previously mentioned, species of this family occur in different environments (dry and humid) from different regions around the world.

The wide distribution of these species is possibly related to the dispersion form, dormant seeds in the soil or seedlings, which indicates the conservation state of the ecosystem and its resilience capacity, meaning its capacity to regenerate even after having experienced strong anthropogenic actions in the past.

It was verified that the estimated basal area was $25.15 \mathrm{~m}^{2} \mathrm{ha}^{-1}$, similar to that recorded by Silva et al. (2012) in a fragment close to the one studied where they registered $26.73 \mathrm{~m}^{2} \mathrm{ha}^{-1}$, suggesting that the community is able to advance in terms of biomass accumulation as expressed by the accumulation of basal area, as the basal area tends to increase with the increase of forest age.

The species with the highest importance values (IV) were Thyrsodium spruceanum, Protium heptaphyllum and Tapirira guianensis, mainly being highlighted by the high number of sampled individuals and for having good distribution in the area.

Floristic diversity estimated by the Shannon index $\left(H^{\prime}\right)$ resulted in 3.60 nats.ind. ${ }^{-1}$ and the Pielou (J) equation was 0.78 , indicating high diversity and uniformity among individuals and species within the plant community. 
Table 2. Phytosociological parameters of tree species inventoried in the Coelha Forest, Usina Trapiche S/A, Sirinhaém, Pernambuco. Data in descending order of IV, in which: $\mathrm{AD}=$ Absolute density in ind/ha; RD = Relative density in \%; $\mathrm{AF}=$ Absolute frequency in $\% ; \mathrm{RF}=$ relative frequency in $\% ; \mathrm{ADo}=$ Absolute dominance in $\mathrm{m}^{2} \mathrm{ha}^{-1}$; $\mathrm{RDo}=$ Relative dominance in $\%$; CV = Coverage value; And IV = Importance value

\begin{tabular}{|c|c|c|c|c|c|c|c|c|}
\hline Species & AD & RD & AF & RF & ADo & RDo & CV & IV \\
\hline Thyrsodium spruceanum & 246 & 18.58 & 97.50 & 5.72 & 2.8496 & 11.3285 & 29.91 & 35.63 \\
\hline Protium heptaphyllum & 134 & 10.12 & 85.00 & 4.99 & 2.8481 & 11.3225 & 21.44 & 26.43 \\
\hline Tapirira guianensis & 68 & 5.14 & 72.50 & 4.25 & 3.1792 & 12.6391 & 17.78 & 22.03 \\
\hline Maprounea guianensis & 29 & 2.19 & 47.50 & 2.79 & 1.6629 & 6.6110 & 8.80 & 11.59 \\
\hline Eschweilera ovata & 52 & 3.93 & 75.00 & 4.40 & 0.4767 & 1.8951 & 5.82 & 10.22 \\
\hline Brosimum guianense & 55 & 4.15 & 72.50 & 4.25 & 0.4557 & 1.8116 & 5.97 & 10.22 \\
\hline Schefflera morototoni & 33 & 2.49 & 57.50 & 3.37 & 0.9510 & 3.7805 & 6.27 & 9.65 \\
\hline Hyeronima alchorneoides & 29 & 2.19 & 47.50 & 2.79 & 0.5798 & 2.3051 & 4.50 & 7.28 \\
\hline Myrcia silvatica & 43 & 3.25 & 55.00 & 3.23 & 0.1820 & 0.7236 & 3.97 & 7.20 \\
\hline Fabaceae 1 & 2 & 0.15 & 5.00 & 0.29 & 1.6373 & 6.5091 & 6.66 & 6.95 \\
\hline Helicostylis tomentosa & 36 & 2.72 & 45.00 & 2.64 & 0.3424 & 1.3611 & 4.08 & 6.72 \\
\hline Miconia affinis & 31 & 2.34 & 47.50 & 2.79 & 0.3878 & 1.5418 & 3.88 & 6.67 \\
\hline Pera ferruginea & 16 & 1.21 & 30.00 & 1.76 & 0.9105 & 3.6195 & 4.83 & 6.59 \\
\hline Casearia javitensis & 35 & 2.64 & 52.50 & 3.08 & 0.1678 & 0.6671 & 3.31 & 6.39 \\
\hline Brosimum rubescens & 39 & 2.95 & 42.50 & 2.49 & 0.2161 & 0.8591 & 3.80 & 6.30 \\
\hline Simarouba amara & 12 & 0.91 & 25.00 & 1.47 & 0.8704 & 3.4604 & 4.37 & 5.83 \\
\hline Himatanthus phagedaenicus & 26 & 1.96 & 37.50 & 2.20 & 0.1385 & 0.5504 & 2.51 & 4.71 \\
\hline Bowdichia virgilioides & 12 & 0.91 & 25.00 & 1.47 & 0.5022 & 1.9965 & 2.90 & 4.37 \\
\hline Ouratea polygyna & 15 & 1.13 & 27.50 & 1.61 & 0.2819 & 1.1209 & 2.25 & 3.87 \\
\hline Miconia hypoleuca & 20 & 1.51 & 32.50 & 1.91 & 0.1044 & 0.4151 & 1.93 & 3.83 \\
\hline Ocotea glomerata & 10 & 0.76 & 22.50 & 1.32 & 0.4078 & 1.6211 & 2.38 & 3.70 \\
\hline Albizia pedicellaris & 6 & 0.45 & 10.00 & 0.59 & 0.6521 & 2.5924 & 3.05 & 3.63 \\
\hline Lecythis lurida & 15 & 1.13 & 32.50 & 1.91 & 0.1065 & 0.4233 & 1.56 & 3.46 \\
\hline Ocotea sp.1 & 13 & 0.98 & 32.50 & 1.91 & 0.1400 & 0.5565 & 1.54 & 3.44 \\
\hline Henriettea succosa & 16 & 1.21 & 32.50 & 1.91 & 0.0785 & 0.3121 & 1.52 & 3.43 \\
\hline Guatteria pogonopus & 17 & 1.28 & 30.00 & 1.76 & 0.0492 & 0.1956 & 1.48 & 3.24 \\
\hline Pouteria bangii & 11 & 0.83 & 20.00 & 1.17 & 0.2712 & 1.0781 & 1.91 & 3.08 \\
\hline Virola gardneri & 12 & 0.91 & 20.00 & 1.17 & 0.2401 & 0.9545 & 1.86 & 3.03 \\
\hline Nectandra cuspidata & 10 & 0.76 & 22.50 & 1.32 & 0.2176 & 0.8649 & 1.62 & 2.94 \\
\hline Eriotheca macrophylla & 6 & 0.45 & 7.50 & 0.44 & 0.4605 & 1.8307 & 2.28 & 2.72 \\
\hline Symphonia globulifera & 12 & 0.91 & 17.50 & 1.03 & 0.1960 & 0.7794 & 1.69 & 2.71 \\
\hline Pourouma acutiflora & 6 & 0.45 & 12.50 & 0.73 & 0.3622 & 1.4398 & 1.89 & 2.63 \\
\hline Pogonophora schomburgkiana & 13 & 0.98 & 17.50 & 1.03 & 0.1468 & 0.5837 & 1.57 & 2.59 \\
\hline Erythroxylum mucronatum & 14 & 1.06 & 22.50 & 1.32 & 0.0438 & 0.1743 & 1.23 & 2.55 \\
\hline Parkia pendula & 8 & 0.60 & 15.00 & 0.88 & 0.2183 & 0.8680 & 1.47 & 2.35 \\
\hline Undetermined 1 & 9 & 0.68 & 20.00 & 1.17 & 0.0917 & 0.3647 & 1.04 & 2.22 \\
\hline Chamaecrista sp.1 & 14 & 1.06 & 10.00 & 0.59 & 0.1244 & 0.4946 & 1.55 & 2.14 \\
\hline Myrcia spectabilis & 11 & 0.83 & 15.00 & 0.88 & 0.0860 & 0.3419 & 1.17 & 2.05 \\
\hline Miconia tomentosa & 11 & 0.83 & 17.50 & 1.03 & 0.0443 & 0.1759 & 1.01 & 2.03 \\
\hline Cupania racemosa & 11 & 0.83 & 17.50 & 1.03 & 0.0336 & 0.1334 & 0.96 & 1.99 \\
\hline Miconia pyrifolia & 9 & 0.68 & 15.00 & 0.88 & 0.0860 & 0.3418 & 1.02 & 1.90 \\
\hline Buchenavia tetraphylla & 1 & 0.08 & 2.50 & 0.15 & 0.4111 & 1.6345 & 1.71 & 1.86 \\
\hline Cordia sellowiana & 7 & 0.53 & 17.50 & 1.03 & 0.0642 & 0.2552 & 0.78 & 1.81 \\
\hline Plathymenia foliolosa & 3 & 0.23 & 7.50 & 0.44 & 0.2197 & 0.8735 & 1.10 & 1.54 \\
\hline Protium giganteum & 7 & 0.53 & 12.50 & 0.73 & 0.0477 & 0.1895 & 0.72 & 1.45 \\
\hline Inga thibaudiana & 6 & 0.45 & 10.00 & 0.59 & 0.0906 & 0.3603 & 0.81 & 1.40 \\
\hline Ocotea sp.2 & 3 & 0.23 & 7.50 & 0.44 & 0.1710 & 0.6799 & 0.91 & 1.35 \\
\hline Siparuna guianensis & 5 & 0.38 & 12.50 & 0.73 & 0.0377 & 0.1497 & 0.53 & 1.26 \\
\hline Myrcia splendens & 6 & 0.45 & 12.50 & 0.73 & 0.0160 & 0.0636 & 0.52 & 1.25 \\
\hline
\end{tabular}


Table 2. Continued...

\begin{tabular}{|c|c|c|c|c|c|c|c|c|}
\hline Species & AD & RD & AF & RF & ADo & RDo & $\mathbf{C V}$ & IV \\
\hline Fabaceae 4 & 5 & 0.38 & 7.50 & 0.44 & 0.0968 & 0.3850 & 0.76 & 1.20 \\
\hline Cupania revoluta & 5 & 0.38 & 7.50 & 0.44 & 0.0774 & 0.3076 & 0.69 & 1.13 \\
\hline Cupania emarginata & 2 & 0.15 & 5.00 & 0.29 & 0.1590 & 0.6321 & 0.78 & 1.08 \\
\hline Lacistema robustum & 5 & 0.38 & 10.00 & 0.59 & 0.0095 & 0.0379 & 0.42 & 1.00 \\
\hline Chaetocarpus myrsinites & 4 & 0.30 & 7.50 & 0.44 & 0.0630 & 0.2505 & 0.55 & 0.99 \\
\hline Miconia prasina & 6 & 0.45 & 7.50 & 0.44 & 0.0189 & 0.0751 & 0.53 & 0.97 \\
\hline Miconia sp.1 & 4 & 0.30 & 10.00 & 0.59 & 0.0190 & 0.0756 & 0.38 & 0.96 \\
\hline Schoepfia brasiliensis & 5 & 0.38 & 7.50 & 0.44 & 0.0233 & 0.0928 & 0.47 & 0.91 \\
\hline Fabaceae 2 & 4 & 0.30 & 7.50 & 0.44 & 0.0386 & 0.1536 & 0.46 & 0.90 \\
\hline Inga cayennensis & 3 & 0.23 & 7.50 & 0.44 & 0.0540 & 0.2148 & 0.44 & 0.88 \\
\hline Dialium guianense & 3 & 0.23 & 2.50 & 0.15 & 0.1226 & 0.4872 & 0.71 & 0.86 \\
\hline Abarema sp.1 & 3 & 0.23 & 7.50 & 0.44 & 0.0343 & 0.1362 & 0.36 & 0.80 \\
\hline Tovomita mangle & 3 & 0.23 & 7.50 & 0.44 & 0.0308 & 0.1225 & 0.35 & 0.79 \\
\hline Maytenus distichophylla & 3 & 0.23 & 7.50 & 0.44 & 0.0286 & 0.1137 & 0.34 & 0.78 \\
\hline Sclerolobium densiflorum & 3 & 0.23 & 2.50 & 0.15 & 0.0966 & 0.3841 & 0.61 & 0.76 \\
\hline Casearia arborea & 3 & 0.23 & 7.50 & 0.44 & 0.0185 & 0.0734 & 0.30 & 0.74 \\
\hline Xylopia frutescens & 3 & 0.23 & 2.50 & 0.15 & 0.0901 & 0.3581 & 0.58 & 0.73 \\
\hline Myrtaceae 1 & 3 & 0.23 & 7.50 & 0.44 & 0.0084 & 0.0333 & 0.26 & 0.70 \\
\hline Picramnia sp.1 & 4 & 0.30 & 5.00 & 0.29 & 0.0088 & 0.0348 & 0.34 & 0.63 \\
\hline Andira ormosioides & 2 & 0.15 & 5.00 & 0.29 & 0.0385 & 0.1531 & 0.30 & 0.60 \\
\hline Gustavia augusta & 3 & 0.23 & 5.00 & 0.29 & 0.0089 & 0.0356 & 0.26 & 0.56 \\
\hline Guapira opposita & 2 & 0.15 & 5.00 & 0.29 & 0.0258 & 0.1024 & 0.25 & 0.55 \\
\hline Pouteria torta & 2 & 0.15 & 5.00 & 0.29 & 0.0104 & 0.0413 & 0.19 & 0.49 \\
\hline Ocotea sp. 3 & 2 & 0.15 & 5.00 & 0.29 & 0.0104 & 0.0413 & 0.19 & 0.49 \\
\hline Erythroxylum citrifolium & 2 & 0.15 & 5.00 & 0.29 & 0.0081 & 0.0322 & 0.18 & 0.48 \\
\hline Myrcia guianensis & 2 & 0.15 & 5.00 & 0.29 & 0.0057 & 0.0226 & 0.17 & 0.47 \\
\hline Sorocea hilarii & 2 & 0.15 & 5.00 & 0.29 & 0.0051 & 0.0205 & 0.17 & 0.46 \\
\hline Eugenia umbrosa & 2 & 0.15 & 5.00 & 0.29 & 0.0046 & 0.0184 & 0.17 & 0.46 \\
\hline Paypayrola blanchetiana & 2 & 0.15 & 5.00 & 0.29 & 0.0046 & 0.0183 & 0.17 & 0.46 \\
\hline Miconia minutiflora & 3 & 0.23 & 2.50 & 0.15 & 0.0209 & 0.0830 & 0.31 & 0.46 \\
\hline Swartzia pickelii & 3 & 0.23 & 2.50 & 0.15 & 0.0088 & 0.0350 & 0.26 & 0.41 \\
\hline Machaerium hirtum & 1 & 0.08 & 2.50 & 0.15 & 0.0239 & 0.0950 & 0.17 & 0.32 \\
\hline Inga sp.1 & 2 & 0.15 & 2.50 & 0.15 & 0.0047 & 0.0189 & 0.17 & 0.32 \\
\hline Rapanea guianensis & 1 & 0.08 & 2.50 & 0.15 & 0.0231 & 0.0919 & 0.17 & 0.31 \\
\hline Rheedia gardneriana & 1 & 0.08 & 2.50 & 0.15 & 0.0215 & 0.0855 & 0.16 & 0.31 \\
\hline Amaioua sp. 1 & 1 & 0.08 & 2.50 & 0.15 & 0.0137 & 0.0545 & 0.13 & 0.28 \\
\hline Pradosia sp.1 & 1 & 0.08 & 2.50 & 0.15 & 0.0097 & 0.0388 & 0.11 & 0.26 \\
\hline Sloanea guianensis & 1 & 0.08 & 2.50 & 0.15 & 0.0060 & 0.0239 & 0.10 & 0.25 \\
\hline Artocarpus heterophyllus & 1 & 0.08 & 2.50 & 0.15 & 0.0058 & 0.0231 & 0.10 & 0.25 \\
\hline Ocotea gardneri & 1 & 0.08 & 2.50 & 0.15 & 0.0054 & 0.0214 & 0.10 & 0.24 \\
\hline Inga sp.2 & 1 & 0.08 & 2.50 & 0.15 & 0.0039 & 0.0153 & 0.09 & 0.24 \\
\hline Coussarea andrei & 1 & 0.08 & 2.50 & 0.15 & 0.0033 & 0.0130 & 0.09 & 0.24 \\
\hline Erythroxylum squamatum & 1 & 0.08 & 2.50 & 0.15 & 0.0032 & 0.0127 & 0.09 & 0.23 \\
\hline Talisia retusa & 1 & 0.08 & 2.50 & 0.15 & 0.0030 & 0.0118 & 0.09 & 0.23 \\
\hline Vismia guianensis & 1 & 0.08 & 2.50 & 0.15 & 0.0029 & 0.0115 & 0.09 & 0.23 \\
\hline Sloanea garckeana & 1 & 0.08 & 2.50 & 0.15 & 0.0029 & 0.0114 & 0.09 & 0.23 \\
\hline Lecythis pisonis & 1 & 0.08 & 2.50 & 0.15 & 0.0029 & 0.0114 & 0.09 & 0.23 \\
\hline Eugenia umbelliflora & 1 & 0.08 & 2.50 & 0.15 & 0.0026 & 0.0104 & 0.09 & 0.23 \\
\hline Pouteria sp.1 & 1 & 0.08 & 2.50 & 0.15 & 0.0024 & 0.0095 & 0.08 & 0.23 \\
\hline Fabaceae 3 & 1 & 0.08 & 2.50 & 0.15 & 0.0022 & 0.0086 & 0.08 & 0.23 \\
\hline Cupania sp.1 & 1 & 0.08 & 2.50 & 0.15 & 0.0021 & 0.0084 & 0.08 & 0.23 \\
\hline Total & 1,324 & 100 & 1,705 & 100 & 25.1541 & 100 & 200 & 300 \\
\hline
\end{tabular}




\subsection{Diametric and hypsometric distribution}

The diameter distribution showed a $12 \mathrm{~cm}$ amplitude with 8 class centers being characterized by small trees, mainly in the first class center, indicating the regeneration capacity of the plant species (Figure 3). The area mainly presents young individuals, since $60.65 \%$ of the total sampled individuals are in the first class center. The maximum diameter found was $142.50 \mathrm{~cm}$, belonging to an individual only identified as Fabaceae 1 .

The centers of classes 4,5 and 6 presented few individuals; however, these are well represented in the smaller class centers, which indicates occurrence of the successional process. Nevertheless, the centers of classes 7 (Buchenavia tetraphylla) and 8 (Fabaceae 1), which presented one individual, do not occur in the centers of previous classes. This fact may be related to some biotic or abiotic factors.

The vertical distribution of the tree stratum presented five height class centers varying from 2.0 to $20 \mathrm{~m}$, with a mean of $8.29 \mathrm{~m}$ in height. The high number of individuals in the second lowest height class center (Figure 4A) is an important indicator of the forest renewal capacity due to the establishment of these individuals in smaller classes (Pinheiro \& Monteiro, 2009).

Analyzing the basal area values between height classes, it was observed that individuals with height less than 10 meters corresponded to $76.28 \%$ of the total sampled individuals with mean $\mathrm{DAB}$ of $8 \mathrm{~cm}$, representing $27.43 \%$ of the total basal area (Figure 4B). A similar result was recorded by Brandão et al. (2009) in studying an Atlantic Forest fragment in Igarassu, Pernambuco state, where $74 \%$ of the individuals presented height less than $10 \mathrm{~m}$ and $\mathrm{DAB}$ lower than $10 \mathrm{~cm}$.

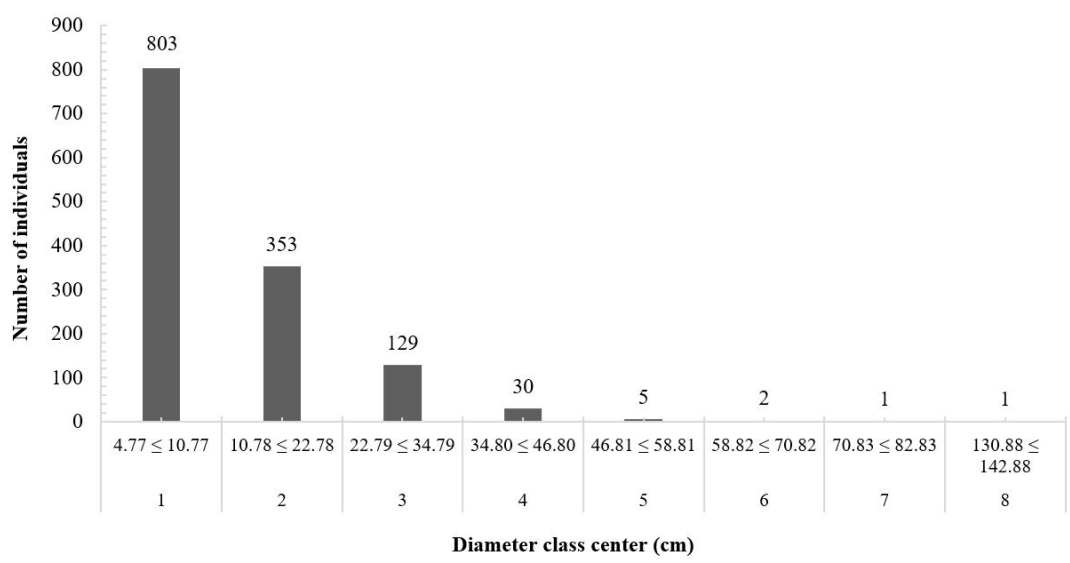

Figure 3. Diameter distribution of arboreal individuals in a Dense Ombrophylous Forest fragment located in the municipality of Sirinhaém, Pernambuco, Brazil.

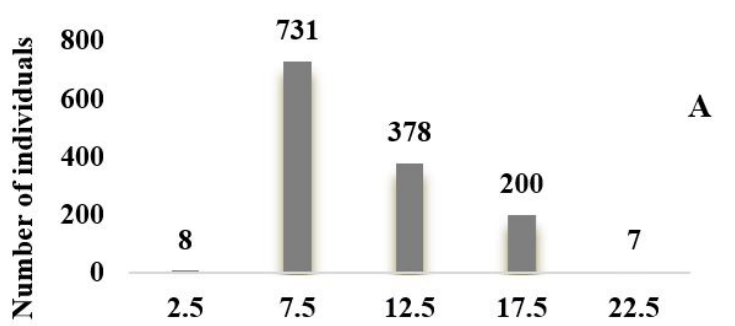

Height class center (m)

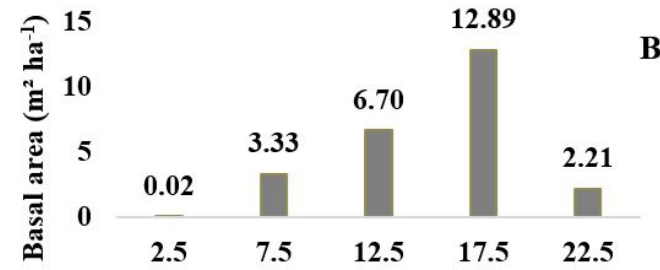

Height class center (m)

Figure 4. Distribution of number of individuals (A) and Absolute Dominance (B) in relation to the height classes in a Dense Ombrophylous Forest fragment located in the municipality of Sirinhaém, Pernambuco, Brazil. 


\section{CONCLUSION}

The studied fragment is very relevant for biodiversity conservation since it presents a significant diversity of species, indicating high uniformity between individuals and species within the plant community.

The diametric structure of the vegetation shows that most of the individuals are in classes with smaller diameters, indicating a community with potential for regeneration, where any anthropic intervention, even if occasional, may directly interfere with its recovery, emphasizing the need for the area's conservation mainly for maintaining the local biodiversity.

The importance of preserving this fragment and others in the regions dominated by sugar cane cultivation must be emphasized, aiming at maintaining the flora and fauna associated with these forest environments.

\section{ACKNOWLEDGEMENTS}

À Coordenação de Aperfeiçoamento de Pessoal de Nível Superior - CAPES, pelo apoio financeiro, e à Usina Trapiche S/A, em especial ao Dr. Cauby, por permitir a pesquisa e dar suporte para realização da mesma.

\section{SUBMISSION STATUS}

Received: 14 may, 2017

Accepted: 30 jun, 2018

\section{CORRESPONDENCE TO}

\section{Rosival Barros de Andrade Lima}

Departamento de Ciências Florestais, Universidade Federal Rural de Pernambuco - UFRPE, Rua Dom Manoel de Medeiros, CEP 52171-900, Recife, PE, Brasil e-mail: rosival_barros@yahoo.com.br

\section{REFERENCES}

Alvares CA, Stape JL, Sentelhas PC, Gonçalves JLM, Sparovek G. Köppen's climate classification map for Brazil. Meteorologische Zeitschrift 2013; 22(6): 711-728. http:// dx.doi.org/10.1127/0941-2948/2013/0507.

Angiosperm Phylogeny Group - APG IV. An update of the Angiosperm Phylogeny Group classification for the orders and families of flowering plants: APG IV. Botanical Journal of the Linnean Society 2016; 1: 1-20.

Brandão CFLS, Alves Júnior FT, Lana MD, Marangon LC, Feliciano ALP. Distribuição espacial, sucessão e dispersão do componente arbóreo em remanescente de floresta atlântica, Igarassu-Pernambuco. Revista Verde 2011; 6(2): 218-229.

Brandão CFLS, Marangon LC, Ferreira RLC, Silva ACBL. Estrutura fitossociológica e classificação sucessional do componente arbóreo em um fragmento de floresta atlântica em Igarassu-Pernambuco. Agrária 2009; 4(1): 55-61. http://dx.doi.org/10.5039/agraria.v4ila9.

Colwell RK. EstimateS 9.1.0. Storrs: Department of Ecology \& Evolutionary Biology, University of Connecticut; 2013.

Cordeiro J, Roderjan CV, Rodrigues WA. Plantas lenhosas da Floresta Ombrófila Mista do Parque Municipal das Araucárias - Guarapuava (PR). Ambiência 2011; 7(3): 441-460. http://dx.doi.org/10.5777/ambiencia.2011.03.03.

Costa RF Jr, Ferreira RLC, Rodal MJN, Feliciano ALP, Marangon LC, Silva WC. Estrutura fitossociológica do componente arbóreo de um fragmento de Floresta Ombrófila Densa na Mata Sul de Pernambuco, Nordeste do Brasil. Ciência Florestal 2008; 18(3): 173-183. http:// dx.doi.org/10.5902/19805098455.

Gandolfi S, Leitão-Filho HF, Bezerra CLF. Levantamento florístico e caráter sucessional das espécies arbustivoarbóreas de uma floresta mesófila semidecídua no município de Guarulhos, SP. Revista Brasileira de Biologia 1995; 55(4): 753-767.

Guimarães FJP, Ferreira RLC, Marangon LC, Silva JAA, Aparício PS, Alves-Júnior FT. Estrutura de um fragmento florestal no Engenho Humaitá, Catende, Pernambuco, Brasil. Revista Brasileira de Engenharia Agrícola e Ambiental 2009; 13(suppl): 940-947. http://dx.doi.org/10.1590/ S1415-43662009000700017.

Hernández-Ramírez AM, García-Méndez S. Diversidad, estructura y regeneración de la selva tropical estacionalmente seca de la Península de Yucatán, México. Revista de Biología Tropical 2015; 63(3): 603-616. PMid:26666118.

Laurance WF, Camargo JLC, Fearnside PM, Lovejoy TE, Williamson GB, Mesquita RCG et al. An Amazonian rainforest and its fragments as a laboratory of global change. Biological Reviews of the Cambridge Philosophical Society 2017; 93(1): 223-247. http://dx.doi.org/10.1111/ brv.12343. PMid:28560765.

Magurran AE. Ecological diversity and its measurement. London: Croom Helm; 1988. http://dx.doi.org/10.1007/97894-015-7358-0.

Malczewski FL, Fritsch M, Povaluk M. Ocorrência de Fabaceae-Mimosoidea em APPs da faixa de domínio da rodovia BR-116, trecho Curitiba, PR a Capão Alto, SC. Saúde e meio ambiente: revista interdisciplinar 2014; 3(2): 102-117. 
Martins L, Cavararo R. Manual Técnico da Vegetação Brasileira: sistema fitogeográfico, inventário das formações florestais e campestres, técnicas e manejo de coleções botânicas, procedimentos para mapeamentos. Rio de Janeiro: IBGE; 2012.

Oliveira LSB, Marangon LC, Feliciano ALP, Lima AS, Cardoso MO, Silva VF. Florística, classificação sucessional e síndromes de dispersão em um remanescente de Floresta Atlântica, Moreno-PE. Agrária 2011; 6(3): 502-507. http:// dx.doi.org/10.5039/agraria.v6i3a1384.

Oliveira PRS, Guedes RVS, Silva CAWS, Santos EP, Oliveira FP, Silva-Júnior HD et al. Boletim do clima: síntese climática/Agência pernambucana de águas e clima. Recife: APAC; 2016.

Pell SK, Mitchell JD, Miller AJ, Lobova TA. Anacardiaceae. In: Kubitzki K, editor. The families and genera of vascular plants. X. Flowering plants. Eudicots. Sapindales, Cucurbitales, Myrtales. Berlin: Springer; 2011.

Pielou EC. Ecological diversity. New York: J. Wiley; 1975.

Pinheiro MH, Monteiro R. Análise estrutural e considerações sobre a dinâmica sucessional de dois fragmentos florestais semideciduais do Jardim Botânico Municipal de Bauru, SP, Brasil. Acta Botanica Brasílica 2009; 23(4): 968-975. http://dx.doi.org/10.1590/S0102-33062009000400007.

Philippi A Jr, Sampaio CAC, Fernandes V. Gestão de natureza pública e sustentabilidade. Barueri: Manole; 2012.

Roa-Romero HA, Salgado-Mora MG, Alvarez-Herrera J. Analysis of the Structure Arborea Agroforestry System Cocoa (Theobroma cacao L.) in Soconusco, ChiapasMexico. Acta Biologica Colombiana 2009; 14(3): 97-110.

Santos HG, Almeida JA, Oliveira JB, Lumbreras JF, Anjos LHC, Coelho MR et al. Sistema brasileiro de classificação de solos. Brasília: Embrapa; 2013.

Silva APFF, Bentes-Gama MM. Fitossociologia de uma Floresta Ombrófila Aberta em área de assentamento rural no distrito de Jaci Paraná, Porto Velho, Rondônia. Ambiência 2008; 4(3): 435-452. http://dx.doi.org/10.5777/ ambiencia.2008.03.06.
Silva FBR, Santos JCP, Silva AB, Cavalcanti AC, Silva FHBB, Burgos $\mathrm{N}$ et al. Zoneamento agroecológico do Estado de Pernambuco. Recife: Embrapa Solos UEP Recife; 2001.

Silva KE, Martins SV, Ribeiro CA, Santos NT, Azevedo $\mathrm{CP}$, Matos FD et al. Floristic composition and similarity of 15 hectares in Central Amazon, Brazil. Revista de Biología Tropical 2011; 59(4): 1927-1938. PMid:22208103.

Silva KE, Matos FDA, Ferreira MM. Composição florística e fitossociologia de espécies arbóreas do Parque Fenológico da Embrapa Amazônia Ocidental. Acta Amazonica 2008; 38(2): 213-222. http://dx.doi.org/10.1590/S004459672008000200004 .

Silva RKS, Feliciano ALP, Marangon LC, Lima RBA, Santos WB. Estrutura e síndromes de dispersão de espécies arbóreas em um trecho de mata ciliar, Sirinhaém, Pernambuco, Brasil. Pesquisa Florestal Brasileira 2012; 32(69): 1-11. http://dx.doi.org/10.4336/2012.pfb.32.69.01.

Silva WC, Marangon LC, Ferreira RLC, Feliciano ALP, Aparício PS, Costa-Júnior RF. Estrutura horizontal e vertical do componente arbóreo em fase de regeneração natural na Mata Santa Luzia, no Município de Catende - PE. Revista Árvore 2010; 34(5): 863-869. http://dx.doi. org/10.1590/S0100-67622010000500011.

Sturges HA. The Choice of a Class Interval. Journal of the American Statistical Association 1926; 21(153): 6566. http://dx.doi.org/10.1080/01621459.1926.10502161.

Tropicos.org. Tropicos [online]. Saint Louis: Missouri Botanical Garden; 2017 [cited 2017 Jan 10]. Available from: http://www.tropicos.org

Téo SJ, Fiorentin LD, Schneider CR, Costa RH, Batista S. Estrutura da regeneração natural sujeita à pecuária extensiva na região de Caçador-SC. Nativa (Sinop) 2014; 02(4): 199-207. http://dx.doi.org/10.14583/2318-7670. v02n04a03.

Vega H, Cetzal-ix W, Mó E, Romero-Soler K. Nuevos registros para la flora de Honduras y el Parque Nacional Montana de Celaque. Acta Biologica Colombiana 2016; 21(3): 635-644. http://dx.doi.org/10.15446/abc.v21n3.51020. 